\title{
Recycling of biomass and coal fly ash as cement replacement material and its effect on hydration and carbonation of concrete
}

\author{
E.R. Teixeira ${ }^{\text {a,*, }}$ A. Camões ${ }^{a}$, F.G. Branco ${ }^{b}$, J.B. Aguiar ${ }^{a}$, R. Fangueiro ${ }^{\text {a }}$ \\ ${ }^{a}$ CTAC, Department of Civil Engineering, School of Engineering, University of Minho, Campus de Azurém, 4800-058 Guimarães, Portugal \\ b ISISE, Department of Civil Engineering, University of Coimbra, RuaLuís Reis Santos - Pólo II da Universidade, 3030 - 788 Coimbra, Portugal
}

\section{A R T I C L E I N F O}

\section{Article history:}

Received 5 December 2018

Revised 25 March 2019

Accepted 24 May 2019

\section{Keywords:}

Biomass fly ash

Coal fly ash

Hydration

Carbonation

Pastes

Concrete

\begin{abstract}
A B S T R A C T
The construction sector has been using supplementary materials in concrete production worldwide, such as coal fly ash. Nowadays, several sub/products or wastes have been studied to be incorporated in construction materials, and one of those wastes is biomass fly ash. However, using high volumes of these materials has some drawbacks, one of them being carbonation. In order to understand phenomena such as this, it is important to study the interaction between the additions and hydration of cement. This paper focuses on the study of hydration and carbonation of cementitious pastes containing biomass fly ash and/ or coal fly ash by using thermogravimetric analysis and X-ray diffraction analysis and by accelerated carbonation tests. BFA present different chemical and mineralogical composition than CFA. The results show that incorporating biomass fly ash into construction materials has a similar carbonation behaviour to coal fly ash. Biomass fly ash seems to give some extra alkalinity to the mixtures, and this may present benefits to the construction materials and for the ash management.
\end{abstract}

(c) 2019 Elsevier Ltd. All rights reserved.

\section{Introduction}

Pozzolanic materials containing silica and alumina compounds with a low degree of crystallization present in their composition (Jain, 2012). These materials are rich in siliceous or aluminosiliceous compounds that in the presence of moisture, chemically react with calcium hydroxide to form products that have cementitious properties (Bediako, 2018). The pozzolanic reactivity is connected to the internal structure of the material (Cordeiro et al., 2011; Van et al., 2013).

Calcium hydroxide is one of the most important reaction products in Portland cement hydration. $\mathrm{Ca}(\mathrm{OH})_{2}$ does not contribute greatly to the mechanical strength of hydrated cement paste. However, its presence makes a very important contribution regarding the protection of the concrete reinforcement against corrosion, since they contribute to an alkaline pH (Bertolini et al., 2004; Papadakis, 2000a; Shi et al., 2011). Pozzolanic materials react with calcium hydroxide and produce silicate hydrates, which are the principle binding compounds in cement (Wang et al., 2008a). Pozzolans minimize the limitations of cement and add additional cementitious material, which leads to an increase in the concrete strength (Dembovska et al., 2017; Schneider et al., 2011;

\footnotetext{
* Corresponding author at: CTAC, Department of Civil Engineering, School of Engineering, University of Minho, Campus de Azurém, 4800-058 Guimarães, Portugal.
}

Shannag, 2000). The pozzolanic material leads to a slower strength gain and a longer setting time, but after long term curing ages, concrete is often stronger and more durable than a plain cement concrete (Chen et al., 2013; Dembovska et al., 2017; Isaia et al., 2003).

The use of renewable sources, such as biomass, to produce heat and power has been increasing in recent years and it is part of the energetic strategies all over the world (Tarelho et al., 2015; Teixeira et al., 2016b). An important issue related to thermochemical conversion of biomass to energy is related to the ashes produced, their characteristics and management (Tarelho et al., 2015). In Portugal, there are no guidelines for biomass fly ash management. The ashes are classified as an industrial solid waste, with code 100103 according to the (European List of Wastes, 2000) and is usually managed by disposal in landfill. However, this disposal has economic, environmental and sustainable implications (Ban and Ramli, 2011; Miller et al., 2006; Tarelho et al., 2012). In some countries, fly ash is sometimes recycled in agricultural fields or forests, but in most cases without controlling it (Rajamma et al., 2015). Therefore, it is important to find alternative applications for fly ash from biomass combustion, in order to make the valorisation of this material and save natural resources (Miller et al., 2006; Tarelho et al., 2015, 2012).

Several types of biomass, during their combustion, produce ash with pozzolanic activity similar to the most common pozzolana (coal fly ash - CFA) in concrete such as: rice husk, wheat straw, 
sugar cane straw and wood (Wang and Baxter, 2007). The characteristics of ash and its management are very important in terms of operating and environmental aspects (Tarelho et al., 2012; Teixeira et al., 2016b).

Using biomass fly ash (BFA) as a partial substitute for cement in building materials will minimise the use of natural resources used in cement production (Tarelho et al., 2012), mitigation of greenhouse gas emissions and a better solution for ash management, avoiding the landfilling of the biomass combustion residues (Tosti et al., 2018). Nowadays, the use of fly ash in concrete is regulated by European standard (EN 450-1, 2012). Some studies showed good performances when blends of coal and biomass fly ash or only biomass ash were used in concrete (Ban and Ramli, 2011; Barbosa et al., 2013; Cordeiro et al., 2009; Rajamma et al., 2009; Wang et al., 2008b).

However, the European standard does not take into account any material not derived from coal combustion, which limits the use of biomass fly ash in cement because coal-fired power plants can use only up to $20 \%$ of biomass to replace coal. (Tosti et al., 2018). However, some studies have demonstrated that biomass fly ash can be used as cement replacement material to produce concrete with good mechanical and durability performance (Ban and Ramli, 2011).

The effect of BFA on the concrete properties is dependent on the physical-chemical characteristics of the biomass fly ash (type of biomass feedstock combusted, the thermal conversion system and the flue gas cleaning system (Obernberger et al., 1997; Sarabèr, 2014; Tarelho et al., 2015). Siddique and Wang et al. observed that the mechanical strength of concrete decreased with increasing wood ash content but, when pozzolanic activity is present, the strength increases with the age (Siddique, 2012; Wang et al., 2008b). Furthermore, biomass fly ash with high calcium content can contain reactive crystalline phases that can contribute to strength development, and some researches focuses their work in higher replacements (20-40\%wt) (Lothenbach et al., 2011; Tosti et al., 2018).

Usually, pozzolanas, such as BFA, are used by replacing some portion of cement. This leads to a decrease in the cement requirement, which then results in a decrease in the total cost of concrete and reduces its carbon footprint as the production of each ton of cement results in $\mathrm{CO}_{2}$ emission of approximately one ton (Hasanbeigi et al., 2012; Kuder et al., 2012; Paris et al., 2016; Shi et al., 2011). So, using biomass fly ash as cement replacement material, helps concrete to change ash from environmental concern to a useful resource with the production of a highly effective alternative cementitious material (Chowdhury et al., 2014; Nagrockienè and Daugèla, 2018; Teixeira et al., 2019, 2016b).

Besides that, one important disadvantage related to the incorporation of pozzolans in concrete is the carbonation phenomenon that can lead to reinforcement corrosion. This phenomenon is even worse in high cement substitutions by pozzolanic materials. Therefore, it is important to understand the carbonation of calcium hydroxide $\left(\mathrm{CH}\right.$ or $\left.\mathrm{Ca}(\mathrm{OH})_{2}\right)$ and the calcium silicate hydrate $(\mathrm{CSH})$ formation process. The carbonate reacts with $\mathrm{Ca}^{2+}$ from $\mathrm{CH}, \mathrm{CSH}$ and the hydrated calcium aluminates and this leads to the formation of different forms of calcium carbonates (Borges et al., 2010). In the initial phase of carbonation, porosity decreases mainly due to the fact that $\mathrm{CH}$ is the first phase attacked and the volume of calcite produced is greater than the volume of $\mathrm{CH}$ (Borges et al., 2010; Morandeau et al., 2014; Reis et al., 2014). Usually, the carbonate samples present an increase in their weight, a lower porosity and a higher compressive strength at early ages (Borges et al., 2010). This usually occurs in low porosity pastes, where calcite formation decreases porosity, preventing $\mathrm{CO}_{2}$ diffusion, reducing carbonation attacks. Pastes with a high porosity could allow the diffusion of a constant $\mathrm{CO}_{2}$ content, in which case the $\mathrm{CH}$ is depleted and the interlayer calcium from $\mathrm{CSH}$ also reacts with the $\mathrm{CO}_{2}$ (Borges et al., 2010; Morandeau et al., 2014).

Concrete with blended cement pastes has a lower $\mathrm{CH}$ content due to the pozzolanic reaction, and for that reason the carbonation of $\mathrm{C}-\mathrm{S}-\mathrm{H}$ is more dependent on the permeability of pastes. High permeable pastes have a rapid decalcification of C-S-H by carbonation shrinkage (Borges et al., 2010; Lilkov et al., 2014).

It is important to study the content of $\mathrm{Ca}(\mathrm{OH})_{2}$ and the carbonation products when pozzolans are used in a high level of cement replacement. Various studies have been done for $\mathrm{Ca}(\mathrm{OH})_{2}$ in cement pastes containing pozzolanas by thermogravimetric analysis (Antoni, 2013; Kroehong et al., 2011; Morandeau et al., 2014; Pacheco Torgal et al., 2012).

Thermogravimetric analysis (TGA) is a method adopted when the objective is to characterize the reactivity of the pozzolanic mixture, mainly in terms of the hydration and kinetic reaction rate and the study of the hydration reaction products. The main aim of this method is to determine the loss masses that are attributed to different compounds, which occur in different temperature classes. For example, the $\mathrm{C}-\mathrm{S}-\mathrm{H}$ has a loss mass essentially in the class of $100-200{ }^{\circ} \mathrm{C}$. On the other hand, portlandite is in the range of $350-450^{\circ} \mathrm{C}$ (Anjos et al., 2017). Several other methods can be used, such as mineralogy analysis by diffraction of X-ray (XRD) or scanning electron microscopy, as can be seen in (Haha et al., 2010; Lee and Lee, 2015; Shi et al., 2016).

The main goal of this work was to evaluate the effect of using $\mathrm{BFA}$, as cement replacement, on the hydration compounds and on the extent of carbonation in cement pastes, using TGA and XRD analysis and by accelerated carbonation tests. During the study, a comparison between plain cement pastes and pastes with BFA or/and pastes with CFA was made.

\section{Materials and methods}

\subsection{Materials}

Portland cement CEM I 42.5R, coal fly ash and biomass fly ash were used to produce cementitious pastes. Portland cement was obtained from the Secil Industry and is produced according to (NP EN 197-1, 2001).

CFA was sampled from a Portuguese thermoelectric power plant that burned coal as fuel. BFA was sampled in a Portuguese pulp and paper industry, which used forest residues, such as bark from eucalyptus and pine, as fuel to produce heat and power. Both ashes were characterised in terms of loss on ignition, chemical composition and thermal analysis. The two ashes were grinded in order to obtain samples with a particle size lower than $90 \mu \mathrm{m}$ for its characterisation in terms of loss on ignition (LOI), chemical and thermogravimetric analysis. The chemical composition was determined by X-Ray Fluorescence (XRF) using a Panalytical Axios spectrometer. The thermal analysis (TG and DTA) was done using a STA, Netzsch $402 \mathrm{EP}$ with a heating rate of $10^{\circ} \mathrm{C} / \mathrm{min}$.

\subsection{Methods}

Four different cement pastes were set, using coal and biomass fly ash as supplementary cementitious materials (Table 3). The content of fly ash in blended cement pastes was $50 \mathrm{wt} \%$ by mass of cement. A constant water-binder ratio of 0.5 was used. The selection of these quantities was due to the fact that this study focused on the effect that BFA can have on the part corresponding to the binder of high volume fly ash concrete (with $50 \mathrm{wt} \%$ of cement replacement), as a solution for the conventional concretes. Usually, a conventional plain cement concrete presents a binder with $350 \mathrm{~kg} / \mathrm{m}^{3}$ and a water-binder ratio of 0.5 . 
The pastes were mixed in a standard mechanical mixer as described in (NP EN 196-1, 2006), for three minutes, and six cubic specimens with $20 \mathrm{~mm}$ edge for each formulation were cast. After demoulding, which was made after $24 \mathrm{~h}$, all samples were cured in a humidity chamber (with approximately $87 \%$ of relative humidity and $21{ }^{\circ} \mathrm{C}$ of temperature) up to the date of the tests (28 and 90 days).

The samples were milled until all particles had a diameter below $63 \mu \mathrm{m}$ and stored in a bag closed using a vacuum system, before the TGA and XRD analysis. The TGA and XRD were done according to what was described before. It was important to seal the samples before the TGA and DRX analysis, to prevent the process of sample carbonation that occurs when the samples contact with $\mathrm{CO}_{2}$ present in the atmosphere. The thermal analysis was carried out using a STA, Netzsch $402 \mathrm{EP}$ with a heating rate of $10^{\circ} \mathrm{C} /$ min and XRD was done in a Bruker D8 Discover diffractometer (Teixeira et al., 2016a).

The level of free calcium hydroxide presented in the pastes after hydration was calculated by Eq. (1). The overall hydration was determined according to Eq. (2), which represents the chemically combined water content (Anjos et al., 2017; Baert et al., 2008). The calculation of calcium carbonate was made according to Eq. (3).

$\mathrm{CH}_{\mathrm{F}}=\mathrm{Ca}(\mathrm{OH})_{2}[\%]=\mathrm{ML}_{\mathrm{Ca}(\mathrm{OH})_{2}}[\%] \cdot M M_{\mathrm{Ca}(\mathrm{OH})_{2}} / \mathrm{MM}_{\mathrm{H}_{2} \mathrm{O}}$

$\mathrm{H}_{2} \mathrm{O}_{\mathrm{Q}, \text { comb }}=\operatorname{mass}(\operatorname{loss} \%)_{1000 \hat{A}^{\circ} \mathrm{C}}-\operatorname{mass}(\operatorname{loss} \%)_{105 \hat{A}^{\circ} \mathrm{C}}$

$\mathrm{CaCO}_{3}[\%]=\mathrm{ML}_{\mathrm{CaCO}_{3}}[\%] \cdot \mathrm{MM}_{\mathrm{CaO}} / \mathrm{MM}_{\mathrm{CO}_{2}}$

where

$\mathrm{CH}_{\mathrm{F}}$ is the content of free calcium hydroxide produced during the hydrate of the paste; $\mathrm{ML}_{\mathrm{Ca}(\mathrm{OH}) 2}$ is the mass loss in \% observed in the TG curve for $\mathrm{Ca}(\mathrm{OH})_{2} ; \mathrm{MM}_{\mathrm{Ca}(\mathrm{OH}) 2}$ is the molecular weight of $\mathrm{Ca}(\mathrm{OH})_{2} ; \mathrm{MM}_{\mathrm{H} 2 \mathrm{O}}$ is the molecular weight of $\mathrm{H}_{2} \mathrm{O} ; \mathrm{H}_{2} \mathrm{O}_{\mathrm{Q} \text {,comb }}$ is chemically combined water; mass $($ loss $\%) 1000^{\circ} \mathrm{C}$ is the total mass loss from 0 to $1000{ }^{\circ} \mathrm{C}$; mass $(\text { loss } \%)_{105^{\circ} \mathrm{C}}$ is mass loss referring to free water, from 35 to $105{ }^{\circ} \mathrm{C} ; \mathrm{ML}_{\mathrm{CaCO}}[\%]$ is the mass loss in \% observed in $\mathrm{TG}$ curve for $\mathrm{CaCO}_{3} ; \mathrm{MM}_{\mathrm{CaO}}$ is the molecular weight for $\mathrm{CaO}$; and $\mathrm{MM}_{\mathrm{CO} 2}$ is the molecular weight of $\mathrm{CO}_{2}$.

The hydration degree $(\alpha)$ was calculated, which is the weight fraction of original cement that has become completely hydrated $(0 \leq \alpha \leq 1)$ (Aiad et al., 2017), as observed in Eq. (4).

$\alpha=\frac{W_{n}}{W_{\infty}}$

where: $\alpha$ is the hydration degree; $\mathrm{W}_{\mathrm{n}}$ is the combined water content (\%) at a presented curing age; and $\mathrm{W}_{\infty}$ is the whole combined water content after full hydration (approximately 0.23 ). The factor of 0.23 represents the non-evaporable water content per gram of cement in a mix for complete hydration (Aiad et al., 2017; Lam et al., 2000).

The carbonation reaction of those pastes was investigated by thermal analysis but was also measured in paste samples, using the accelerated carbonation test. For the carbonation test, three samples for each paste formulation with the dimensions of $40 \times 40 \times 160 \mathrm{~mm}^{3}$ were prepared. The samples were cured in a humidity chamber with relative humidity and temperature control (with approximately $87 \%$ of relative humidity and $21^{\circ} \mathrm{C}$ of temperature). After curing, the cured samples were preconditioned in an isolated container subjected to constant temperature and relative humidity $(\mathrm{RH})\left(88.0 \pm 4.0 \%\right.$ and $\left.17.5 \pm 1.6{ }^{\circ} \mathrm{C}\right)$ for 14 days, to ensure the stabilization of humidity within the samples. To measure the depth of carbonation, the samples were sealed with paraffin, with the exception of two opposite faces. After sealing, the samples were placed in an accelerated carbonation chamber $(4.1 \pm 0.1 \%$ of
$\mathrm{CO}_{2}, 43.7 \pm 16.2 \% \mathrm{RH}$ and $\left.20.0 \pm 0.0^{\circ} \mathrm{C}\right)$. To measure the carbonation depth, cross-sections were sprayed with a phenolphthalein indicator, based on the procedure described in (CEN/TS 1239012, 2010; LNEC E 391, 1993). The pastes were compared at 28 and 90 days of curing.

Carbonation mainly occurs because $\mathrm{CO}_{2}$ adsorption in alkaline media to form $\mathrm{CaCO}_{3}$, decreasing the $\mathrm{pH}$ value of mixes. For this reason, the $\mathrm{pH}$ was measured in the samples before and after curing, and after the accelerated carbonation test finished. Solid samples of milled pastes were placed in a glass with distilled water at a solid to liquid ratio of $1: 20$. The glass was covered with plastic film to prevent the evaporation of water and the reaction of water with the atmospheric $\mathrm{CO}_{2}$ and was stored for $24 \mathrm{~h}$. The procedure used in this study was based on (McPolin et al., 2007). After $24 \mathrm{~h}$, the $\mathrm{pH}$ of each sample was measured using Crisonmicro pH 2000 equipment.

\section{Results and discussion}

\subsection{Physical and chemical characterization of cement, CFA and BFA}

The data on the physical and chemical analysis of cement was obtained via the datasheet provided by the manufacturer, and are showed in Table 1.The Portland cement presented a specific weight of $3.12 \mathrm{~g} / \mathrm{cm}^{3}$ and a Blaine specific surface of $4072 \mathrm{~cm}^{2} / \mathrm{g}$. In terms of chemical composition, a higher percentage of calcium oxide, more than $63 \mathrm{wt} \%$, followed by silicon oxide (around 20 wt\%) and aluminium oxide (3.4 wt\%) is observed. These values are expected and usual for a Portland cement (Gesoğlu et al., 2013; Tangchirapat et al., 2009).

The obtained LOI and the chemical composition of the selected materials are showed in Table 2. As can be seen, BFA showed a LOI value of $6.27 \%$ and CFA presented a value of $2.73 \%$. Silica is the major chemical element $(54.08 \% \mathrm{wt})$ present in the CFA, followed by $\mathrm{Al}_{2} \mathrm{O}_{3}, \mathrm{Fe}_{2} \mathrm{O}_{3}, \mathrm{CaO}$ and $\mathrm{K}_{2} \mathrm{O}$. $\mathrm{SiO}_{2}$ was also the major chemical present in BFA (36.03\%), followed by $\mathrm{CaO}, \mathrm{Al}_{2} \mathrm{O}_{3}, \mathrm{~K}_{2} \mathrm{O}, \mathrm{Fe}_{2} \mathrm{O}_{3}, \mathrm{MgO}$. CFA represents a typical composition of Class $\mathrm{F}$ fly ash, according to (ASTM C618-15, 2015). However, BFA is not included in the ASTM C618 classes, since the sum of $\mathrm{SiO}_{2}+\mathrm{Al}_{2} \mathrm{O}_{3}+\mathrm{Fe}_{2} \mathrm{O}_{3}$ is lower than $50 \%$.

Table 1

Physical and chemical characteristics of cement (Secil - Companhia Geral de Cal e Cimentos, 2013)

\begin{tabular}{|c|c|c|}
\hline \multirow{2}{*}{$\begin{array}{l}\text { Analysis } \\
\text { Chemical composition }\end{array}$} & \multicolumn{2}{|c|}{$\begin{array}{l}\text { Average of values measure in } \\
\text { one year }\end{array}$} \\
\hline & & \\
\hline Loss on ignition (\%) & & 2.33 \\
\hline Insoluble Residue (\%) & & 1.35 \\
\hline $\mathrm{SiO}_{2}(\%)$ & & 19.07 \\
\hline $\mathrm{Al}_{2} \mathrm{O}_{3}(\%)$ & & 4.43 \\
\hline $\mathrm{Fe}_{2} \mathrm{O}_{3}(\%)$ & & 3.50 \\
\hline $\mathrm{CaO}(\%)$ & & 63.80 \\
\hline $\operatorname{MgO}(\%)$ & & 1.87 \\
\hline $\mathrm{SO}_{3}(\%)$ & & 3.28 \\
\hline $\mathrm{K}_{2} \mathrm{O}(\%)$ & & 0.90 \\
\hline $\mathrm{Na}_{2} \mathrm{O}(\%)$ & & 0.21 \\
\hline $\mathrm{Cl}^{-}(\%)$ & & 0.05 \\
\hline \multicolumn{3}{|l|}{ Physical Composition } \\
\hline Specific weight $\left(\mathrm{g} / \mathrm{cm}^{3}\right)$ & & 3.12 \\
\hline Blaine specific surface $\left(\mathrm{cm}^{2} / \mathrm{g}\right)$ & & 4072 \\
\hline \multirow[t]{2}{*}{ Sieve Residue (\%) } & $45 \mu \mathrm{m}$ & 3.20 \\
\hline & $32 \mu \mathrm{m}$ & 9.26 \\
\hline Water demand (\%) & & 28.8 \\
\hline \multirow[t]{2}{*}{ Setting Time (min) } & Initial & 189 \\
\hline & Final & 260 \\
\hline Soundness (mm) & & 0.84 \\
\hline
\end{tabular}


Table 2

Physical and chemical composition and loss-on-ignition of BFA and CFA samples.

\begin{tabular}{lll}
\hline Parameters & Materials & \\
\cline { 2 - 3 } & $\mathrm{CFA}$ & $\mathrm{BFA}$ \\
\hline Chemical characteristics (by FRX) & $\% \mathrm{wt}$ & \\
$\mathrm{SiO}_{2}$ & 54.08 & 36.03 \\
$\mathrm{CaO}$ & 3.27 & 27.41 \\
$\mathrm{Na}_{2} \mathrm{O}$ & 0.51 & 0.87 \\
$\mathrm{Al}_{2} \mathrm{O}_{3}$ & 26.38 & 8.33 \\
$\mathrm{MgO}_{\mathrm{K}} \mathrm{O}$ & 1.55 & 3.56 \\
$\mathrm{P}_{2} \mathrm{O}_{5}$ & 1.64 & 4.92 \\
$\mathrm{SO}_{3}$ & 0.80 & 3.21 \\
$\mathrm{Cl}$ & 0.98 & 3.18 \\
$\mathrm{TiO}_{2}$ & - & 0.60 \\
$\mathrm{MnO}_{\mathrm{Fe}} \mathrm{O}_{3}$ & 1.44 & 0.94 \\
Loss on ignition & 0.05 & 0.24 \\
Physical characteristics & 6.12 & 4.12 \\
Diameter for 10\% of retained material $(\mu \mathrm{m})$ & 2.73 & 6.27 \\
Diameter for 50\% of retained material $(\mu \mathrm{m})$ & & \\
Diameter for 90\% of retained material $(\mu \mathrm{m})$ & 1.53 & 5.91 \\
Bulk density $\left(\mathrm{kg} / \mathrm{m}^{3}\right)$ & 20.19 & 46.70 \\
& 2420 & 230.74 \\
& & 2619
\end{tabular}

The thermogravimetric (TG) and DTA signals registered for cement, CFA and BFA are shown in Fig. 1. A slight decrease was observed around $100{ }^{\circ} \mathrm{C}$ for both ashes. This loss of weight is related to the release of water adsorbed in the ash. With increasing temperature, a significant decrease in weight of the two fly ashes was observed in the range of $600-835^{\circ} \mathrm{C}$, associated with an endothermic process. This weight loss must be related to the ther-
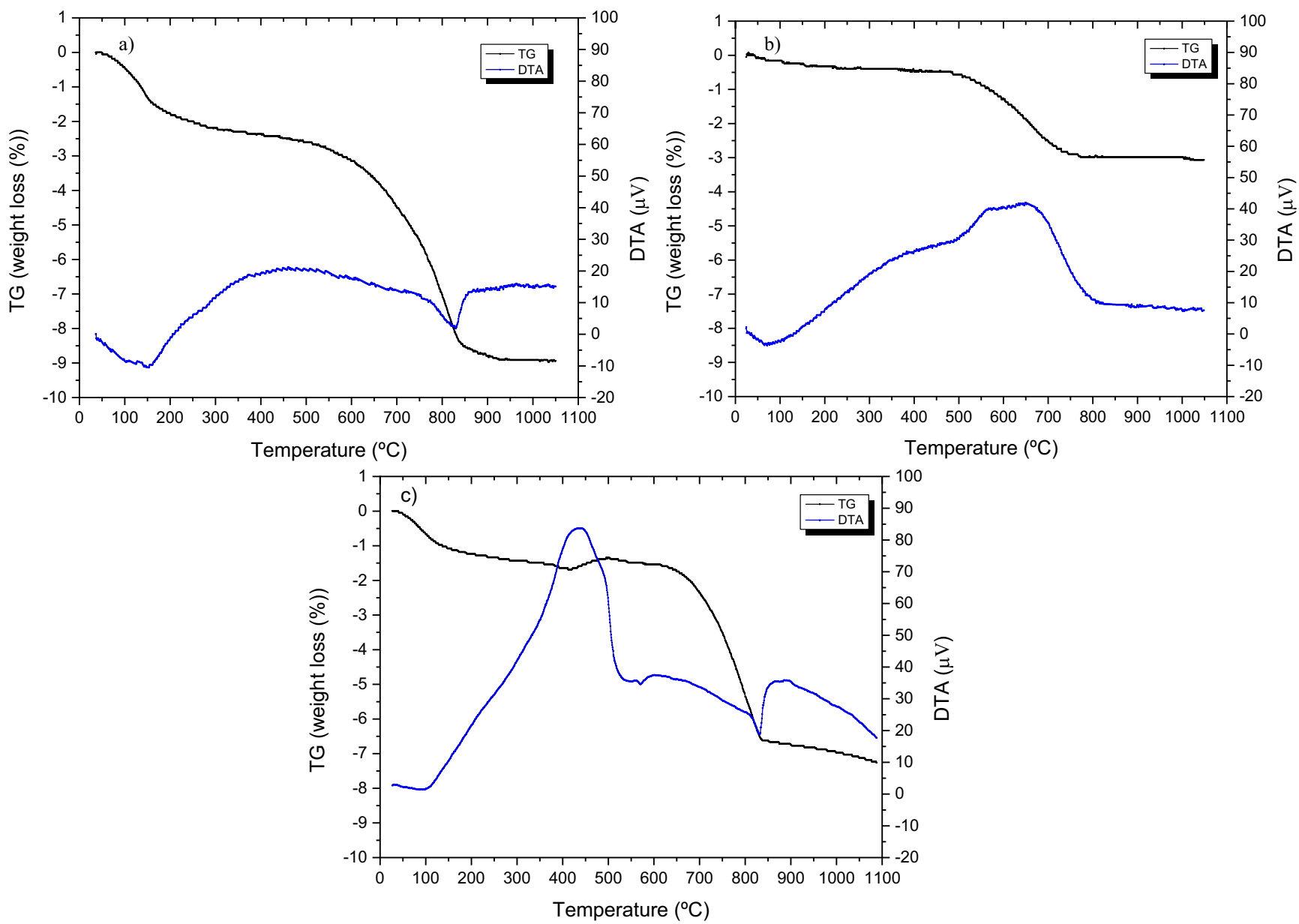

Fig. 1. Thermogravimetric analysis of: Cement (a), CFA (b) and BFA (c).
Table 3

Paste Formulations.

\begin{tabular}{lllll}
\hline Nomenclature & \% of Cement & \% of CFA & \% of BFA & w/b ratio \\
\hline 100C & 100 & 0 & 0 & 0.5 \\
50C-50CFA & 50 & 50 & 0 & 0.5 \\
50C-50BFA & 50 & 0 & 50 & 0.5 \\
50C-25CFA-25BFA & 50 & 25 & 25 & 0.5 \\
\hline
\end{tabular}

mal decomposition of carbonates such as $\mathrm{CaCO}_{3}$ (Teixeira et al., 2016a). The total weight loss was approximately 2-3\% for the CFA and $6-7 \%$ for BFA and these results are similar to the values observed in LOI analysis (Table 2). The thermal behaviour of the biomass fly ash and coal fly ash presented in this study is similar to that described in other researches (Girón et al., 2013; Li et al., 2017; Tarelho et al., 2015; Vassilev et al., 2013a).

\subsection{Thermal analysis}

\subsubsection{Chemically combined water and degree of hydration of pastes}

Fig. 2 presents the TG/DTA curves of the tested hydrated pastes at 28 and 90 days of curing. The TG/DTA profiles showed typical reactions occurring in cement hydrated pastes, when submitted to a continuous increase in temperature. The differences were related to the values of mass loss verified for each hydrated product and for the carbonated products, as shown in Table 4, where the values obtained in pastes at 28 and 90 days are shown.

The first peak observed in the graphs of TG/DTA was related to the loss of free water that occurs between 0 and $105^{\circ} \mathrm{C}$. The water in the large pores evaporated for temperatures up to $35^{\circ} \mathrm{C}$. Above 

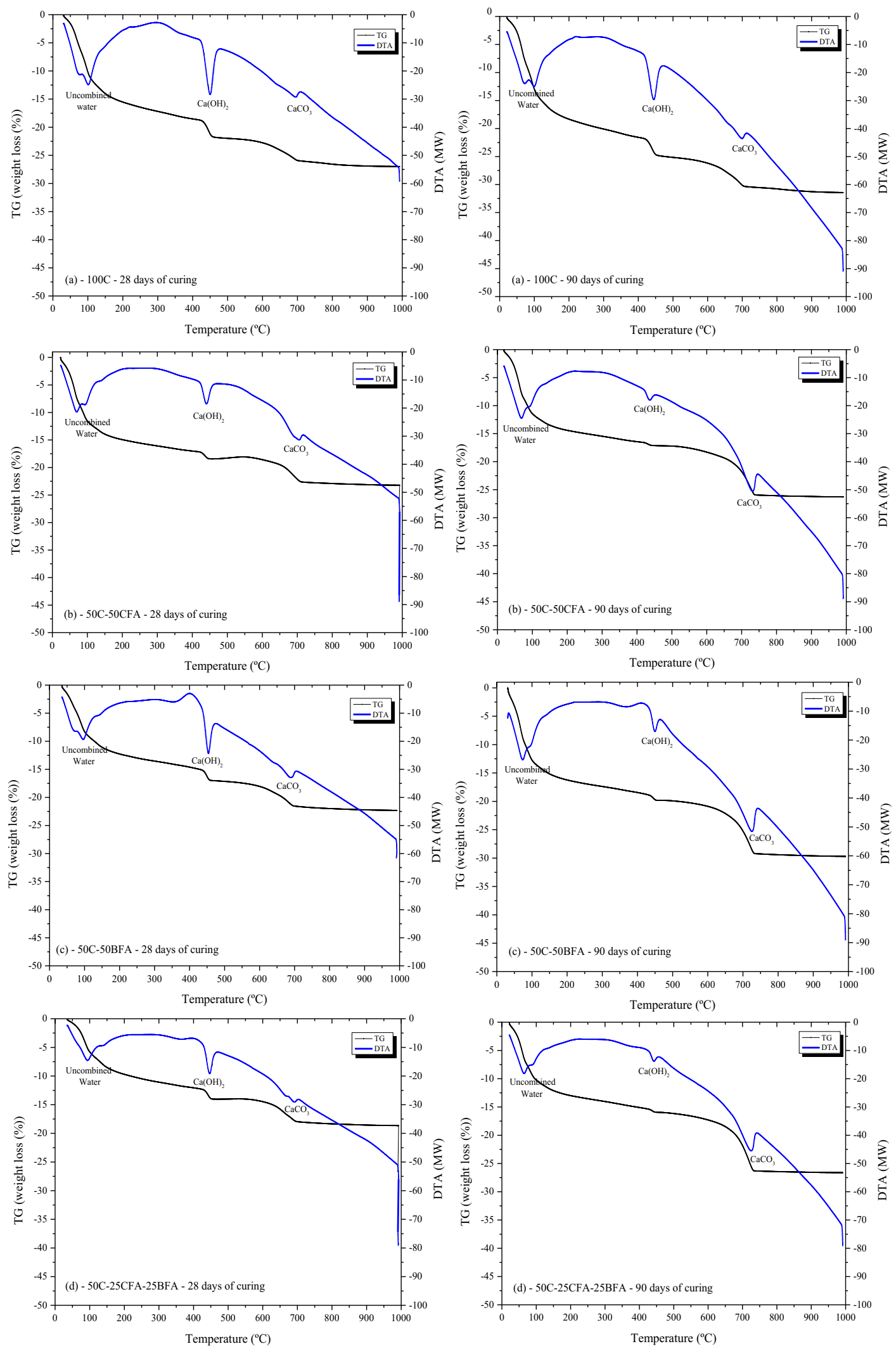

Fig. 2. Thermogravimetric analysis of $100 \mathrm{C}$ (a), 50C-50CFA (b), 50C-50BFA (c) and 50C-25CFA-25BFA (d) specimens.

this temperature, the retained water is released by capillarity tension in the capillarity pores (Anjos et al., 2017). The water that is not chemically combined is not used for the calculation of the level of hydration (Alarcon-Ruiz et al., 2005; Anjos et al., 2017; Baert et al., 2008). A weight reduction of samples was observed for temperatures between 150 and $400{ }^{\circ} \mathrm{C}$ (Fig. 2). This is due to the evap- 
Table 4

Mass losses at 28 and 90 days.

\begin{tabular}{|c|c|c|c|c|c|c|c|c|}
\hline \multirow[t]{2}{*}{ Sample } & \multicolumn{2}{|c|}{ Uncombined water } & \multicolumn{2}{|c|}{$\mathrm{Ca}(\mathrm{OH})_{2}(\mathrm{wt} \%)$} & \multicolumn{2}{|c|}{$\mathrm{CaCO}_{3}(\mathrm{wt} \%)$} & \multicolumn{2}{|c|}{ Total mass loss } \\
\hline & at 28 days & at 90 days & at 28 days & at 90 days & at 28 days & at 90 days & at 28 days & at 90 days \\
\hline $100 \mathrm{C}$ & 9.66 & 11.78 & 3.46 & 3.32 & 2.79 & 3.15 & 27.00 & 31.44 \\
\hline 50C-50FA & 10.21 & 9.97 & 1.30 & 0.67 & 3.15 & 6.05 & 23.23 & 26.30 \\
\hline 50C-50BFA & 8.27 & 11.62 & 2.32 & 1.27 & 2.97 & 6.83 & 22.33 & 29.70 \\
\hline 50C-25FA-25BFA & 5.80 & 8.83 & 1.88 & 0.84 & 2.98 & 7.62 & 18.65 & 26.63 \\
\hline
\end{tabular}

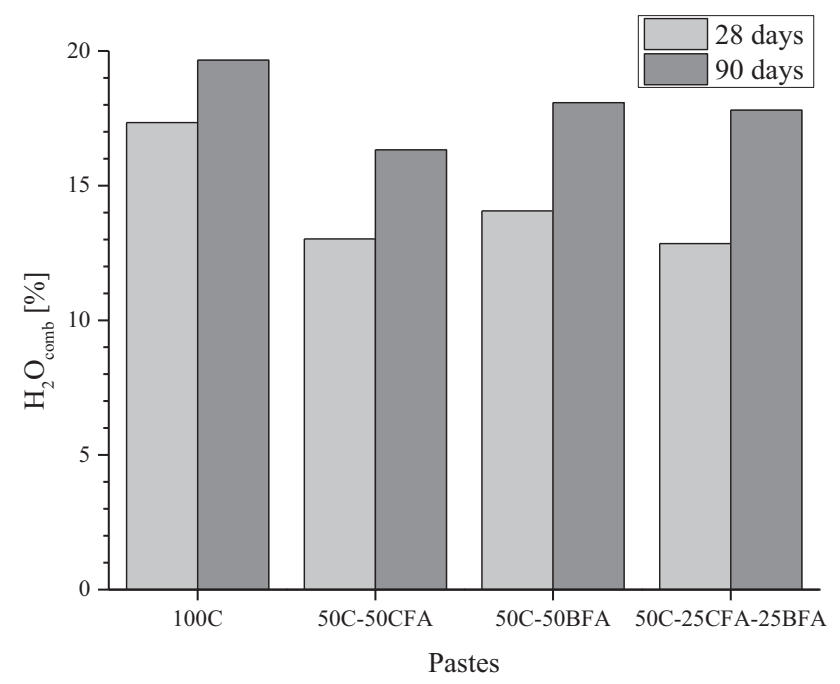

Fig. 3. Chemically combined water content after 28 and 90 days.

oration of the physically combined water from the reaction products (for example C-S-H gel and alumino silicate gel) (Bernal et al., 2011; Kong and Sanjayan, 2010; Lee and Lee, 2015).

Fig. 3 shows the chemically combined water found in hydrated pastes after 28 and 90 days, determined by Eq. (2) (as described in Section 2.2). The rate of increase of the chemically water content from 28 and 90 days was $13.4,25.4,28.6$ and $38.5 \%$ for $100 C$, 50C-50CFA, 50C-50BFA and 50C-25CFA-25BFA, respectively. (Eq. (4))

The degree of hydration obtained for the hardened cement pastes can be found in Table 6. It can be observed that the degree of hydration was similar for all samples, and the hydration degree values of pastes with fly ash were lower than of the reference sample.

\subsection{2. $\mathrm{Ca}(\mathrm{OH})_{2}$ content}

The $\mathrm{Ca}(\mathrm{OH})_{2}$ content for the different pastes is presented in Table 5. This compound is formed during the hydration of dicalcium silicate $\left(\mathrm{C}_{2} \mathrm{~S}\right)$ and tricalcium silicate $\left(\mathrm{C}_{3} \mathrm{~S}\right)$ contained in the cement. Some authors showed that for cement CEM I 42.5, this is formed at 3 days of curing (Sisomphon and Franke, 2011). One of

Table 5

The degree of hydration $(\alpha)$ of the hardened cement pastes.

\begin{tabular}{lll}
\hline Sample & Days & \\
\cline { 2 - 3 } & 28 & 90 \\
\hline 100C & 0.75 & 0.86 \\
50C-50CFA & 0.57 & 0.71 \\
50C-50BFA & 0.61 & 0.79 \\
50C-25CFA-25BFA & 0.56 & 0.77 \\
\hline
\end{tabular}

the most noted peaks on the TG/DTA curve (Fig. 3) corresponds to the mass related with the dehydroxylation of calcium hydroxide, which occurs between the temperatures of 410 and $480^{\circ} \mathrm{C}$ (Scrivener et al., 2015). The content of free calcium hydroxide is an important parameter to assess the hydration and is shown in Fig. 5.

Pastes with CFA and BFA showed a significant reduction in the level of free calcium hydroxide with an increase in the age of hydration, when compared to the cement paste. This can be explained by the pozzolanic reactions and with the calcium hydroxide $(\mathrm{CH})$ produced by the hydration of cement (Anjos et al., 2017). A $50 \mathrm{wt} \%$ cement replacement was studied for each paste sample. If the ash contributed nothing to the pozzolanic reaction, the $\mathrm{Ca}(\mathrm{OH})_{2}$ presented in the samples with ash should be 50 $w t \%$ of that determined for the plain cement paste. On the contrary, if the two ashes were highly pozzolanic, the $\mathrm{Ca}(\mathrm{OH})_{2}$ would be very low. At 28 days, the $\mathrm{Ca}(\mathrm{OH})_{2}$ of $50 \mathrm{wt} \%$ of CFA, $50 \mathrm{wt} \%$ of cement replaced with BFA and the blend of the two ashes is 38, 67 and $55 \%$ of the value obtained for cement paste, respectively (Fig. 2). The results showed that BFA did not have a contribution for the pozzolanic reaction and seems to add some calcium hydroxide to the paste.

Pastes with CFA and BFA presented a decrease in $\mathrm{Ca}(\mathrm{OH})_{2}$ content at 90 days, but in these pastes the total consumption was not observed. Similar results were observed in (Sakai et al., 2005; Tkaczewska and Małolepszy, 2009). This is related with the pozzolanic reaction but also justified by the carbonation, because during the chemical reaction $\mathrm{Ca}(\mathrm{OH})_{2}$ is consumed to produce calcium carbonate (Chatterji et al., 2002; Jiang et al., 2000; Visser, 2014).

\subsection{3. $\mathrm{CaCO}_{3}$ content}

The last peak observed in the thermogravimetric analysis was related with calcium carbonate $\left(650-800^{\circ} \mathrm{C}\right)$ (Fig. 2). Similar results were observed in various studies (Bernal et al., 2011; Chindaprasirt et al., 2014; Kong and Sanjayan, 2010; Lee and Lee, 2015). The $\mathrm{CaCO}_{3}$ analysis is very important, because it is related with the carbonation phenomena and can consequently affect the corrosion of concrete reinforcement. However, the TG/DTA analysis showed an exothermic signal around $500-650{ }^{\circ} \mathrm{C}$ for CFA and $300-600^{\circ} \mathrm{C}$ for BFA, this weight loss can most probably be a result of elemental carbon oxidation, according to (Rocca et al., 2013; Zomeren and Comans, 2009).

The $\mathrm{CaCO}_{3}$ content for different pastes is presented in Table 4 and was determined by the results expressed in Fig. 4. As can be seen, the content of calcium carbonate was higher for pastes with two types of fly ash than for paste containing cement only. The content of $\mathrm{CaCO}_{3}$ duplicated from 28 to 90 days of curing, with the exception of cement paste $(100 \mathrm{C})$. This is explained by the fact that the carbonation mechanism is a lengthy process due to the low $\mathrm{CO}_{2}$ concentration in atmosphere and the physical characteristics of materials, which allow some resistance to the $\mathrm{CO}_{2}$ penetration (Monteiro, 2010).

In terms of total loss mass (Table 5), an increase of mass loss was observed with the increase of the curing age. This is related to the increase in the $\mathrm{CaCO}_{3}$ content at 90 days. 

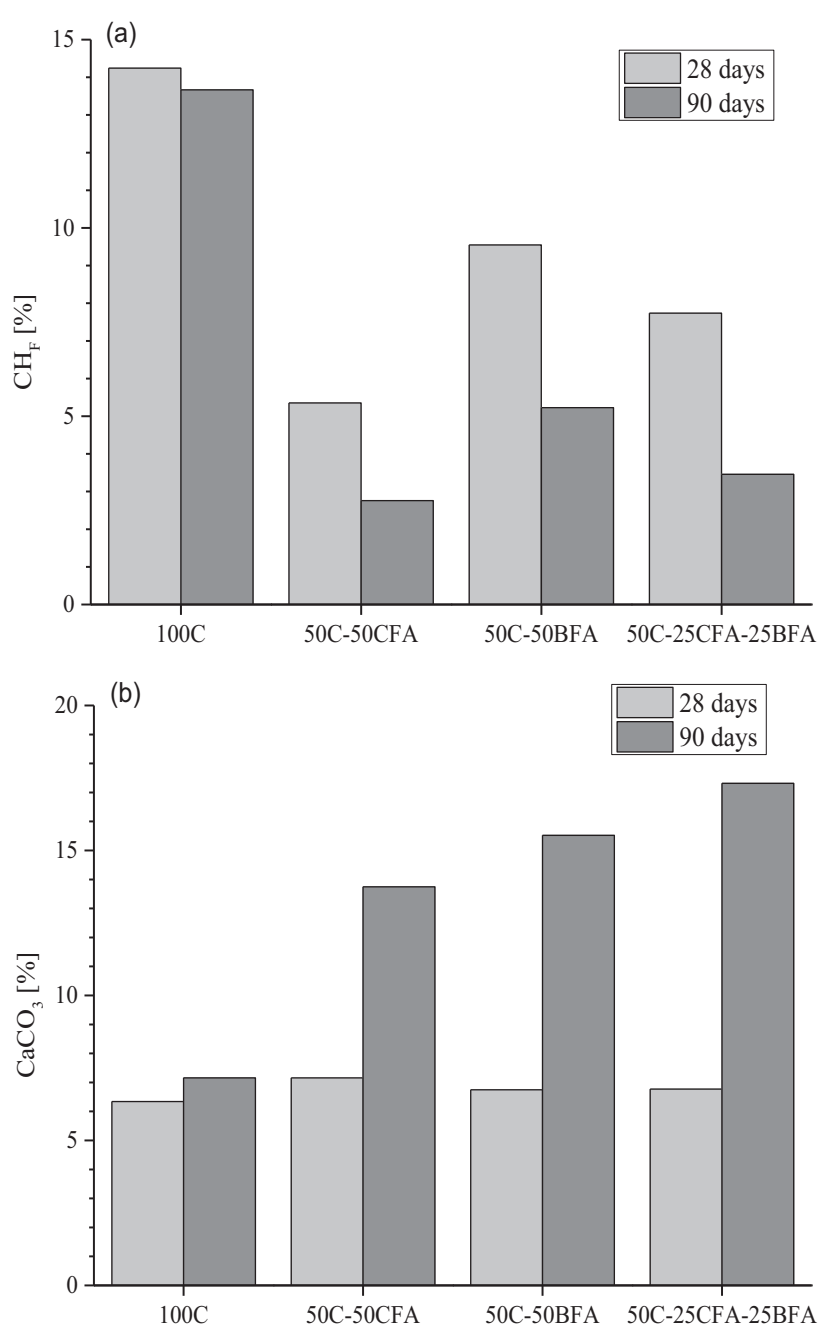

Fig. 4. Content of $\mathrm{CH}_{\mathrm{F}}$ (a) and $\mathrm{CaCO}_{3}$ (b) in pastes after 28 and 90 days.

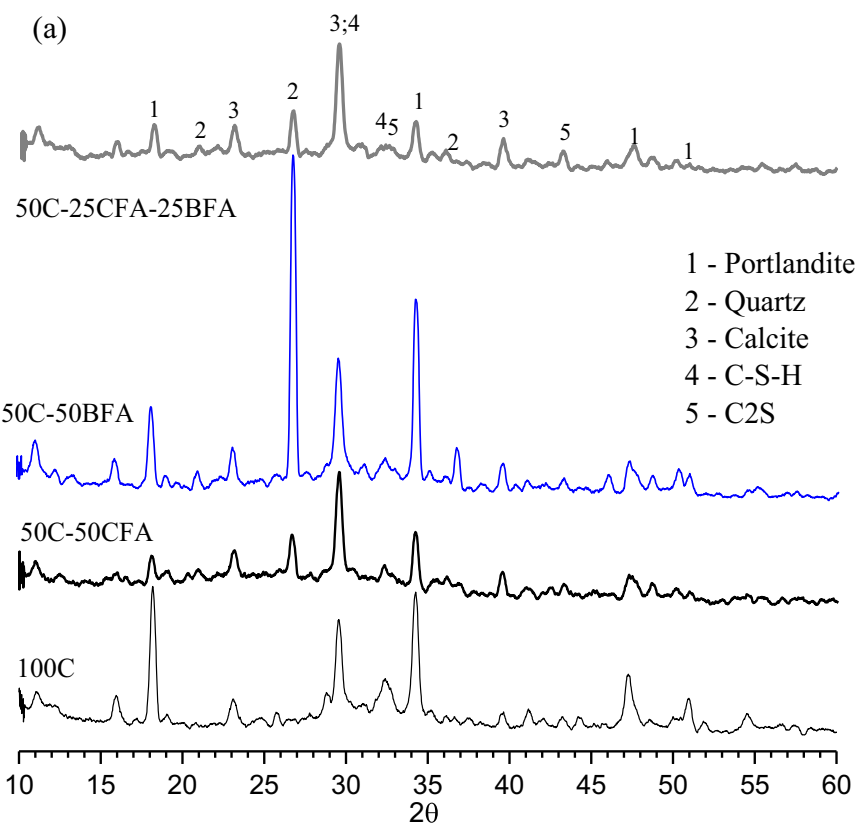

\subsection{Mineralogical analysis of pastes}

Fig. 5 presents the XRD patterns of pastes after28 and 90 days of curing. Calcium silicates are responsible for the gain in mechanical strength of construction materials (Tkaczewska and Małolepszy, 2009) and are part of the chemical composition of Portland cement (Aïtcin, 2008). The presence of $C_{2} S$ peaks for pastes with fly ash can be observed for both ages that show the presence of unhydrated cement grains. $\mathrm{C}_{3} \mathrm{~S}$ peaks were not observed and this is expected, since this compound has a higher reaction rate with respect to $\mathrm{C}_{2} \mathrm{~S}$ (Anjos et al., 2017).

It was verified that the intensity of the portlandite $\left(\mathrm{Ca}(\mathrm{OH})_{2}\right)$ peak was significantly higher for the plain cement mix (Fig. 5) and similar results were observed in (Kocak and Nas, 2014). This indicates higher hydration and corroborates the values obtained from chemically combined water and $\mathrm{CH}_{\mathrm{F}}$ obtained by TG/DTA (Figs. 3 and 4).

A significant increase in the calcite peak was observed between 28 and 90 days for all pastes, but this was related to the cement hydration. BFA pastes presented a significant increase in the $\mathrm{CaCO}_{3}$ peak. As observed in the TGA analysis, the content of calcite differed with the increase in the curing age and this can be seen by the increase in the peak intensity in the XRD analysis.

The presence of quartz in the samples with BFA and CFA (alone or blended) is due to the presence of this compound in the chemical composition of each ash, as seen in Table 2. CFA is usually a little finer than Portland cement, and its major chemical constituents, silica, alumina and iron and calcium oxides (Joshi and Lohita, 2001; Lothenbach et al., 2011; Reis et al., 2016a). Usually, BFA presents a high content of silicium compounds, which is also related with the chemical composition of biomass (mostly with the inorganic part ash), but also related with the inert material, e.g. soil particles, which are fed mixed with biomass during combustion (Vassilev et al., 2010). The high silica content is explained by the fine particles from the inert material fed with biomass and in the case of the bubbling fluidized bed reactor, by the fine particles that belong to the bed sand, which are reduced by the combustion of flue gas and

Fig. 5. XRD patterns for pastes with: (a) 28 days and (b) 90 days. 

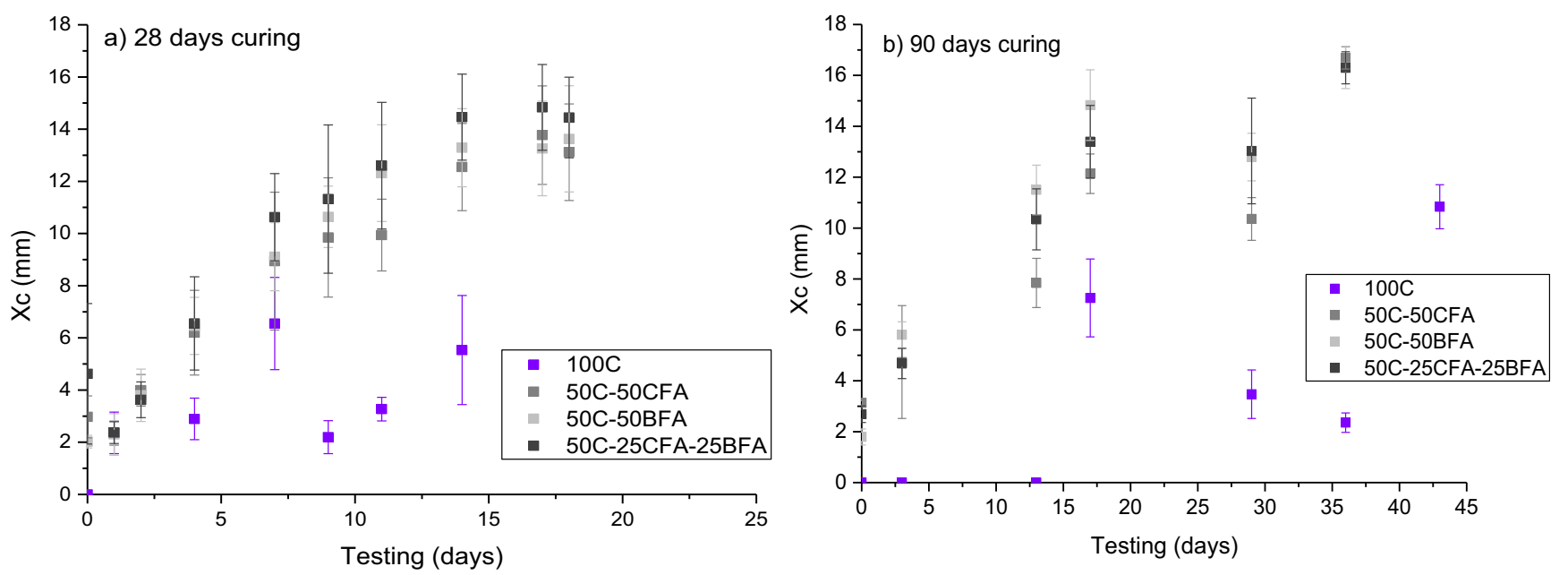

Fig. 6. Variation of carbonation depth for the different pastes.

Table 6

Values of $\mathrm{pH}$ measured in pastes.

\begin{tabular}{|c|c|c|c|c|c|}
\hline \multirow[t]{2}{*}{ Samples } & \multirow[t]{2}{*}{ After demoulded } & \multicolumn{2}{|l|}{28 days } & \multicolumn{2}{|l|}{90 days } \\
\hline & & After curing & After total carbonation (20 days) & After curing & After total carbonation (36 days) \\
\hline $100 \mathrm{C}$ & $12.24 \pm 0.008$ & $12.69 \pm 0.009$ & $11.65 \pm 0.008^{\mathrm{a}}$ & $12.44 \pm 0.012$ & $12.50 \pm 0.012^{\mathrm{a}}$ \\
\hline 50C-50CFA & $12.35 \pm 0.008$ & $12.70 \pm 0.008$ & $9.94 \pm 0.012$ & $12.07 \pm 0.008$ & $10.27 \pm 0.008$ \\
\hline 50C-50BFA & $12.34 \pm 0.005$ & $12.72 \pm 0.000$ & $9.90 \pm 0.012$ & $12.23 \pm 0.009$ & $10.00 \pm 0.005$ \\
\hline 50C-25CFA-25BFA & $12.38 \pm 0.005$ & $12.71 \pm 0.008$ & $9.89 \pm 0.012$ & $12.16 \pm 0.000$ & $9.97 \pm 0.008$ \\
\hline
\end{tabular}

a The $\mathrm{pH}$ value is the value that cement paste had at the time when the samples of pastes with ash are totally carbonated.

captured by the control devices (Tarelho et al., 2015, 2012; Teixeira et al., 2013; Vassilev et al., 2013b, 2010).

\subsection{Accelerated carbonation test using phenolphthalein indicator and pH for cement based pastes}

The results for the carbonation depth for the two curing ages during the test period are presented in Fig. 6. No initial carbonation was observed for any pastes before being exposed to $\mathrm{CO}_{2}$ at the two curing ages. The reference paste showed very slow progress in the carbonation depth. As can be seen, at the two curing ages, pastes that contain ash had a very high carbonation depth when compared to the reference one. Similar results were observed in various studies (Atis, 2003; Khan and Lynsdale, 2002; Khunthongkeaw et al., 2006; Papadakis, 2000b; Reis et al., 2014; Shi et al., 2016) and this is due to the consumption of calcium hydroxide and the consequent decrease in pH (Ramos et al., 2013; Reis et al., 2014; Reis et al., 2016b).

The test was carried out until the sample did not show a colour change, when sprayed with phenolphthalein, which means that the sample is completely carbonated. After 20 days of testing, all fly ash pastes were completed carbonated. On the other hand, during this period the cement paste presented low values of carbonation depth. Similar results were observed for pastes with 90 days of curing. Once again, pastes with fly ash reached the total carbonation of samples after 36 days of testing and the cement paste presented low values of carbonation depth. No significant differences between the values for the carbonation depth were observed in the pastes with fly ash and this confirmed the results shown in the TGA analysis (Table 4). As observed in Table 4, 50C-25FA-25BFA presented the highest values for the calcium carbonate at 28 days of curing. At 90 days, the sample 50C-50BFA presented higher values for the carbonation depth, but at the end of the test the results were similar for all paste samples (Fig. 6).
In Table 6, the values of $\mathrm{pH}$ measured for the different pastes are shown. Pastes with fly ash presented slightly higher values than the reference (100C) for fresh samples. Some authors observed that with the increase in the two fly ash in paste samples, the pH increases (Zhang et al., 2000). There was an increase in the $\mathrm{pH}$ during hydration for 28 and 90 days curing, when compared with the fresh sample.

The $\mathrm{pH}$ decreased when the carbonation was increased from an initial value of around 12.7 to a value in the range of 9-10 after the samples are totally carbonated (Table 6). This decrease is diagnosed to result from carbonation of the high-Ca C-S-H to a decalcified phase C-S-H and calcium carbonate (Shi et al., 2016). The pH analysis of solid samples after the carbonation test was in agreement with the phenolphthalein indicator, which shows colour changes around 9 .

\section{Conclusions}

In this paper, the effect of the use of biomass fly ash on the hydration process and carbonation of construction materials was studied. Pastes with 50 wt\% of cement replacement by coal/biomass fly ash exhibited lower amounts of chemically combined water, compared with the cement paste, from which it can be inferred that the level of cement hydration is lower. The XRD analysis corroborates this achievement and suggests that fly ash increased the kinetics of the cement hydration and that the pozzolanic reaction is still occurring.

The results show that pastes with biomass fly ash promote mixes with higher alkalinity reserves and probably the biomass fly ash increases the hydrated calcium silicates formed in their pozzolanic reaction. A decrease in the calcium hydroxide can be observed in these pastes, when compared to cement paste. However, the content of this compound is much higher than in pastes with coal fly ash, even at 90 days of age. 
In terms of calcium carbonate formation, no significant differences were observed between using coal fly ash or biomass fly ash, which indicated similar resistance to carbonation. However, a higher consumption of calcium hydroxide during the carbonation mechanism of coal fly ash paste was observed. The use of biomass fly ash seems to have a similar behavior to that of the use of coal fly ash in terms of carbonation.

The results show that it is important to carry out future studies using biomass fly ash in concrete, due to the fact that its use has a significant impact on the hydration and carbonation of the pastes and their development over time.

\section{Acknowledgements}

The authors wish to thank the Portuguese Foundation for Science and Technology (FCT) and the Eco-Construction and Rehabilitation Doctoral Program for supporting the PhD scholarship (with the reference $\mathrm{PD} / \mathrm{BD} / 52661 / 2014$ ). This work was also financed by FEDER funds through the Operational Program for Competitive Factors - COMPETE and by national funds through FCT - Foundation for Science and Technology within the scope of the project POCI-01-0145-FEDER-007633 and through the Regional Operational Programme CENTRO2020 within the scope of the project CENTRO-01- 0145-FEDER- 000006.

\section{References}

Aiad, I., Al-Sabagh, A.M., Shafek, S.H., Adawy, A.I., Abo-EL-Enein, S.A., 2017. Effect of some prepared superplasticizers (Cyclohexanone Based) on compressive strength and physico-chemical properties of oil well cement pastes. Egypt. J. Pet. 26, 843-850. https://doi.org/10.1016/j.ejpe.2016.10.019.

Aïtcin, P.-C., 2008. Binders for durable and sustainable concrete, Taylor \& F. ed, Modern Concrete Technology. Taylor \& Francis, London and New York. 10.1017/ CBO9781107415324.004.

Alarcon-Ruiz, L., Platret, G., Massieu, E., Ehrlacher, A., 2005. The use of thermal analysis in assessing the effect of temperature on a cement paste. Cem. Concr. Res. 35, 609-613. https://doi.org/10.1016/j.cemconres.2004.06.015.

Anjos, M.A.S., Reis, R., Camões, A., Duarte, F., Jesus, C., 2017. Evaluation of hydration of cement pastes containing high volume of mineral additions. Eur. J. Environ. Civ. Eng. 8189, 1-17. https://doi.org/10.1080/19648189.2017.1327892.

Antoni, M., 2013. Investigation of cement substitution by blends of calcined clays and limestone. PhD Thesis. Faculty of engineering sciences and techniques. Federal institute of technology in Lausanne.

ASTM C618-15, 2015. Standard specification for coal fly ash and raw or calcined natural pozzolan for use in concrete.

Atis, C.D., 2003. Accelerated carbonation and testing of concrete made with fly ash. Constr. Build. Mater. 17, 147-152. https://doi.org/10.1016/S0950-0618(02) 00116-2.

Baert, G., Hoste, S., De Schutter, G., De Belie, N., 2008. Reactivity of fly ash in cement paste studied by means of thermogravimetry and isothermal calorimetry. J Therm. Anal. Calorim. 94, 485-492. https://doi.org/10.1007/s10973-007-8787-z.

Ban, C.C., Ramli, M., 2011. The implementation of wood waste ash as a partia cement replacement material in the production of structural grade concrete and mortar: an overview. Resour. Conserv. Recycl. 55, 669-685. https://doi.org/ 10.1016/j.resconrec.2011.02.002.

Barbosa, R., Lapa, N., Dias, D., Mendes, B., 2013. Concretes containing biomass ashes: mechanical, chemical, and ecotoxic performances. Constr. Build. Mater. 48, 457-463. https://doi.org/10.1016/j.conbuildmat.2013.07.031.

Bediako, M., 2018. Pozzolanic potentials and hydration behavior of ground waste clay brick obtained from clamp-firing technology. Case Stud. Constr. Mater. 8, 1-7. https://doi.org/10.1016/j.cscm.2017.11.003.

Bernal, S.A., Rodríguez, E.D., de Gutiérrez, R.M., Gordillo, M., Provis, J.L., 2011. Mechanical and thermal characterisation of geopolymers based on silicateactivated metakaolin/slag blends. J. Mater. Sci. 46, 5477-5486. https://doi.org/ 10.1007/s10853-011-5490-z.

Bertolini, L., Elsener, B., Pedeferri, P., Polder, R., 2004. Corrosion of steel in concrete: prevention, diagnosis. Repair. John Wiley \& Sons 2004. https://doi.org/10.1002/ 9780470872864.ch49.

Borges, P.H.R., Costa, J.O., Milestone, N.B., Lynsdale, C.J., Streatfield, R.E., 2010. Carbonation of $\mathrm{CH}$ and $\mathrm{C}-\mathrm{S}-\mathrm{H}$ in composite cement pastes containing high amounts of BFS. Cem. Concr. Res. 40, 284-292. https://doi.org/10.1016/j. cemconres.2009.10.020.

CEN/TS 12390-12, 2010. Testing hardened concrete - Part 12: Determination of the potential carbonation resistance of concrete: Accelerated carbonation method. CEN:Brussels.

Chatterji, S., Snyder, K.A., Marchand, J., 2002. Depth profiles of carbonates formed during natural carbonation. Cem. Concr. Res. 32, 1923-1930. https://doi.org/ 10.1016/S0008-8846(02)00908-0.
Chen, Y.Y., Tuan, B.L.A., Hwang, C.L., 2013. Effect of paste amount on the properties of self-consolidating concrete containing fly ash and slag. Constr. Build. Mater. 47, 340-346. https://doi.org/10.1016/j.conbuildmat.2013.05.050.

Chindaprasirt, P., Paisitsrisawat, P., Rattanasak, U., 2014. Strength and resistance to sulfate and sulfuric acid of ground fluidized bed combustion fly ash-silica fume alkali-activated composite. Adv. Powder Technol. 25, 1087-1093. https://doi. org/10.1016/j.apt.2014.02.007.

Chowdhury, S., Maniar, A., Suganya, O.M., 2014. Strength development in concrete with wood ash blended cement and use of soft computing models to predict strength parameters. J. Adv. Res. 6, 907-913. https://doi.org/10.1016/ j.jare.2014.08.006.

Cordeiro, G.C., Toledo Filho, R.D., Tavares, L.M., Fairbairn, E.de.M.R., 2009. Ultrafine grinding of sugar cane bagasse ash for application as pozzolanic admixture in concrete. Cem. Concr. Res. 39, 110-115. https://doi.org/10.1016/j. cemconres.2008.11.005.

Cordeiro, G.C., Toledo Filho, R.D., Tavares, L.M., Fairbairn, E.D.M.R., Hempel, S., 2011. Influence of particle size and specific surface area on the pozzolanic activity of residual rice husk ash. Cem. Concr. Compos. 33, 529-534. https://doi.org/ 10.1016/j.cemconcomp.2011.02.005.

Dembovska, L., Bajare, D., Pundiene, I., Vitola, L., 2017. Effect of pozzolanic additives on the strength development of high performance concrete. Proc. Eng. 172, 202-210. https://doi.org/10.1016/j.proeng.2017.02.050.

EN 450-1, 2012. Norma Portuguesa, Cinzas volantes para betão, Parte 1: definição, especificações e critérios de conformidade. (Portuguese Norm, Fly ash concrete, Part 1: Definition, specifications and conformity criteria), Instituto Português da Qualidade. Instituto Português da Qualidade.

European List of Wastes, 2000. Commission Decision 2000/532/EC of 3 May 2000, amended by the Commission Decision 2001/118/EC, Commission Decision 2001/119/EC and Council Decision 2001/573/EC. doi:(2000/532/EC)

Gesoğlu, M., Güneyisi, E., Alzeebaree, R., Mermerdas, K., 2013. Effect of silica fume and steel fiber on the mechanical properties of the concretes produced with cold bonded fly ash aggregates. Constr. Build. Mater. 40, 982-990. https://doi. org/10.1016/j.conbuildmat.2012.11.074.

Girón, R.P., Ruiz, B., Fuente, E., Gil, R.R., Suárez-Ruiz, I., 2013. Properties of fly ash from forest biomass combustion. Fuel 114, 71-77. https://doi.org/10.1016/ j.fuel.2012.04.042.

Haha, M. Ben, De Weerdt, K., Lothenbach, B., 2010. Quantification of the degree of reaction of fly ash. Cem. Concr. Res. 40, 1620-1629. https://doi.org/10.1016/j. cemconres.2010.07.004.

Hasanbeigi, A., Price, L., Lin, E. 2012. Emerging energy-efficiency and CO2 emissionreduction technologies for cement and concrete production: a technical review. Renew. Sustain. Energy Rev. 16, 6220-6238. https://doi.org/10.1016/j. rser.2012.07.019.

Isaia, G.C., Gastaldini, A.L.G., Moraes, R., 2003. Physical and pozzolanic action of mineral additions on the mechanical strength of high-performance concrete. Cem. Concr. Compos. 25, 69-76. https://doi.org/10.1016/S0958-9465(01) 00057-9.

Jain, N., 2012. Effect of nonpozzolanic and pozzolanic mineral admixtures on the hydration behavior of ordinary Portland cement. Constr. Build. Mater. 27, 3944. https://doi.org/10.1016/j.conbuildmat.2011.08.006.

Jiang, L., Lin, B., Cai, Y., 2000. A model for predicting carbonation of high-volume fly ash concrete. Cem. Concr. Res. 30, 699-702. https://doi.org/10.1016/S00088846(00)00227-1.

Joshi, R.C., Lohita, R.P., 2001. Fly Ash in Concrete: Production, Properties and Uses. In: 2001 International Ash Utilization Symposium, Advances in Concrete Technology. Center for Applied Energy Research, University of Kentuck.

Khan, M.I., Lynsdale, C.J., 2002. Strength, permeability, and carbonation of highperformance concrete. Cem. Concr. Res. 32, 123-131. https://doi.org/10.1016/ S0008-8846(01)00641-X.

Khunthongkeaw, J., Tangtermsirikul, S., Leelawat, T., 2006. A study on carbonation depth prediction for fly ash concrete. Constr. Build. Mater. 20, 744-753. https:|| doi.org/10.1016/j.conbuildmat.2005.01.052.

Kocak, Y., Nas, S., 2014. The effect of using fly ash on the strength and hydration characteristics of blended cements. Constr. Build. Mater. 73, 25-32. https://doi. org/10.1016/j.conbuildmat.2014.09.048.

Kong, D.L.Y., Sanjayan, J.G., 2010. Effect of elevated temperatures on geopolymer paste, mortar and concrete. Cem. Concr. Res. 40, 334-339. https://doi.org/ 10.1016/j.cemconres.2009.10.017.

Kroehong, W., Sinsiri, T., Jaturapitakkul, C., Chindaprasirt, P., 2011. Effect of palm oil fuel ash fineness on the microstructure of blended cement paste. Constr. Build. Mater. 25, 4095-4104. https://doi.org/10.1016/j.conbuildmat.2011.04.062.

Kuder, K., Lehman, D., Berman, J., Hannesson, G., Shogren, R., 2012. Mechanical properties of self consolidating concrete blended with high volumes of fly ash and slag. Constr. Build. Mater. 34, 285-295. https://doi.org/10.1016/ j.conbuildmat.2012.02.034.

Lam, L., Wong, Y.L., Poon, C.S., 2000. Degree of hydration and gel/space ratio of highvolume fly ash/cement systems. Cem. Concr. Res. 30, 747-756. https://doi.org/ 10.1016/S0008-8846(00)00213-1.

Lee, N.K., Lee, H.K., 2015. Reactivity and reaction products of alkali-activated, fly ash/slag paste. Constr. Build. Mater. 81, 303-312. https://doi.org/10.1016/ j.conbuildmat.2015.02.022.

Li, Y., Lin, H., Wang, Z., 2017. Quantitative analysis of fly ash in hardened cement paste. Constr. Build. Mater. 153, 139-145. https://doi.org/10.1016/ j.conbuildmat.2017.07.106. 
Lilkov, V., Rostovsky, I., Petrov, O., Tzvetanova, Y., Savov, P., 2014. Long term study of hardened cement pastes containing silica fume and fly ash. Constr. Build. Mater. 60, 48-56. https://doi.org/10.1016/j.conbuildmat.2014.02.045.

LNEC E 391, 1993. Especificação LNEC - Betões - Determinação da resistência à carbonatação. LNEC Specification - Concrete - Determination of carbonation resistance, Laboratório Nacional de Engenharia Civil - Portugal.

Lothenbach, B., Scrivener, K., Hooton, R.D., 2011. Supplementary cementitious materials. Cem. Concr. Res. 41, 1244-1256. https://doi.org/10.1016/j. cemconres.2010.12.001.

McPolin, D.O., Basheer, P.A., Long, A.E., Grattan, K.T., Sun, T., 2007. New test method to obtain $\mathrm{pH}$ profiles due to carbonation of concretes containing supplementary cementitious materials. J. Mater. Civ. Eng. 19, 936-946. https://doi.org/10.1061/ (ASCE)0899-1561(2007) 19:11(936).

Miller, B., Dugwell, D., Kandiyoti, R., 2006. The fate of trace elements during the cocombustion of Wood-Bark with waste. Energy \& Fuels 20, 520-531. https://doi. org/10.1021/ef058013r.

Monteiro, I.F.G., 2010. Modelação da evolução da carbonatação em elementos de betão armado ("Modelation of the evaluation on the carbonation of the reiforcement concrete elements"). Master Thesis. Instituto superior técnico. Universidade Técnica de Lisboa.

Morandeau, A., Thiéry, M., Dangla, P., 2014. Investigation of the carbonation mechanism of $\mathrm{CH}$ and $\mathrm{C}-\mathrm{S}-\mathrm{H}$ in terms of kinetics, microstructure changes and moisture properties. Cem. Concr. Res. 56, 153-170. https://doi.org/10.1016/j. cemconres.2013.11.015.

Nagrockienè, D., Daugèla, A., 2018. Investigation into the properties of concrete modified with biomass combustion fly ash. Constr. Build. Mater. 174, 369-375. https://doi.org/10.1016/j.conbuildmat.2018.04.125.

NP EN 196-1, 2006. Norma Portuguesa - Métodos de ensaio de cimentos. Parte 1: Determinação das resistencias mecânicas. Portuguese Norm - Methods for testing cement. Part 1: Determination of strength. IPQ, Instituto Português da Qualidade.

NP EN 197-1, 2001. Cimento - Parte 1: Composição, especificações e critérios de conformidade para cimentos correntes. IPQ - Instituto Portugês da Qualidade.

Obernberger, I., Biedermann, F., Widmann, W., Riedl, R., 1997. Concentrations of inorganic elements in biomass fuels and recovery in the different ash fractions. Biomass Bioenergy 12, 211-224. https://doi.org/10.1016/S0961-9534(96) 00051-7.

Pacheco Torgal, F., Miraldo, S., Labrincha, J.A., De Brito, J., 2012. An overview on concrete carbonation in the context of eco-efficient construction: evaluation, use of SCMs and/or RAC. Constr. Build. Mater. 36, 141-150. https://doi.org/ 10.1016/j.conbuildmat.2012.04.066.

Papadakis, V.G., 2000a. Effect of fly ash on Portland cement systems. Part II. Highcalcium fly ash. Cem. Concr. Res. 30, 1647-1654. https://doi.org/10.1016/ S0008-8846(00)00388-4.

Papadakis, V.G., 2000b. Effect of supplementary cementing materials on concrete resistance against carbonation and chloride ingress. Cem. Concr. Res. 30, 291 299. https://doi.org/10.1016/S0008-8846(99)00249-5.

Paris, J.M., Roessler, J.G., Ferraro, C.C., Deford, H.D., Townsend, T.G., 2016. A review of waste products utilized as supplements to Portland cement in concrete. J. Clean. Prod. 121, 1-18. https://doi.org/10.1016/j.jclepro.2016.02.013.

Rajamma, R., Ball, R.J., Tarelho, L.A.C., Allen, G.C., Labrincha, J.A., Ferreira, V.M., 2009. Characterisation and use of biomass fly ash in cement-based materials. J. Hazard. Mater. 172, 1049-1060. https://doi.org/10.1016/j.jhazmat.2009.07.109.

Rajamma, R., Senff, L., Ribeiro, M.J., Labrincha, J.A., Ball, R.J., Allen, G.C., Ferreira, V. M., 2015. Biomass fly ash effect on fresh and hardened state properties of cement based materials. Compos. Part B 77, 1-9. https://doi.org/10.1016/ j.compositesb.2015.03.019.

Ramos, T., Matos, A.M., Sousa-Coutinho, J., 2013. Mortar with wood waste ash: mechanical strength carbonation resistance and ASR expansion. Constr. Build. Mater. 49, 343-351. https://doi.org/10.1016/j.conbuildmat.2013.08.026.

Reis, R., Camões, A., Ribeiro, M., Raphaele, M., 2016a. Calcium hydroxide curing for accelerated carbonation testing of high volume fly ash cementitious blends. Second Int. Conf. Concr. Sustain., 482-490 https://doi.org/10.1007/s10334-0150487-2.

Reis, R., Malheiro, R., Camões, A., Ribeiro, M., 2014. Carbonation resistance of high volume fly ash concrete. Key Eng. Mater. 634, 288-299. https://doi.org/10.4028/ www.scientific.net/KEM.634.288.

Reis, R., Ribeiro, M.J.P., Abrantes, J.C.C., Camões, A., Teixeira, E., Malheiro, R., 2016b. Methodology for analysis of the reactivity of coal fly ash using selective dissolution by hydrofluoric acid. Key Eng. Mater. 711, 1126-1133. https://doi. org/10.4028/www.scientific.net/KEM.711.1126.

Rocca, S., Zomeren, A. Van, Costa, G., Dijkstra, J.J., Comans, R.N.J., Lombardi, F., 2013. Mechanisms contributing to the thermal analysis of waste incineration bottom ash and quantification of different carbon species. Waste Manag. 33, 373-381. https://doi.org/10.1016/j.wasman.2012.11.004.

Sakai, E., Miyahara, S., Ohsawa, S., Lee, S.H., Daimon, M., 2005. Hydration of fly ash cement. Cem. Concr. Res. 35, 1135-1140. https://doi.org/10.1016/j. cemconres.2004.09.008

Sarabèr, A.J., 2014. Co-combustion and its impact on fly ash quality; full-scale experiments. Fuel Process. Technol. 128, 68-82. https://doi.org/10.1016/ j.fuproc.2014.06.026.

Schneider, M., Romer, M., Tschudin, M., Bolio, H., 2011. Sustainable cement production-present and future. Cem. Concr. Res. 41, 642-650. https://doi.org/ 10.1016/j.cemconres.2011.03.019.

Scrivener, K.L., Lothenbach, B., De Belie, N., Gruyaert, E., Skibsted, J., Snellings, R., Vollpracht, A., 2015. TC 238-SCM: hydration and microstructure of concrete with SCMs: state of the art on methods to determine degree of reaction of SCMs. Mater. Struct. Constr. 48, 835-862. https://doi.org/10.1617/s11527-015-05274.

Secil - Companhia Geral de Cal e Cimentos, 2013. Autocontrol Results - Portland Cement.

Shannag, M.J., 2000. High strength concrete containing natural pozzolan and silica fume. Cem. Concr. Compos. 22, 399-406. https://doi.org/10.1016/S0958-9465 (00)00037-8.

Shi, C., Jiménez, A.F., Palomo, A., 2011. New cements for the 21st century: the pursuit of an alternative to Portland cement. Cem. Concr. Res. 41, 750-763. https://doi.org/10.1016/j.cemconres.2011.03.016.

Shi, Z., Lothenbach, B., Geiker, M.R., Kaufmann, J., Leemann, A., Ferreiro, S., Skibsted, J., 2016. Experimental studies and thermodynamic modeling of the carbonation of Portland cement, metakaolin and limestone mortars. Cem. Concr. Res. 88, 6072. https://doi.org/10.1016/j.cemconres.2016.06.006.

Siddique, R., 2012. Utilization of wood ash in concrete manufacturing. Resour Conserv. Recycl. 67, 27-33. https://doi.org/10.1016/j.resconrec.2012.07.004.

Sisomphon, K., Franke, L., 2011. Evaluation of calcium hydroxide contents in pozzolanic cement pastes by a chemical extraction method. Constr. Build. Mater. 25, 190-194. https://doi.org/10.1016/j.conbuildmat.2010.06.039.

Tangchirapat, W., Jaturapitakkul, C., Chindaprasirt, P., 2009. Use of palm oil fuel ash as a supplementary cementitious material for producing high-strength concrete. Constr. Build. Mater. 23, 2641-2646. https://doi.org/10.1016/ j.conbuildmat.2009.01.008.

Tarelho, L.A.C., Teixeira, E.R., Silva, D.F.R., Modolo, R.C.E., Labrincha, J.A., Rocha, F., 2015. Characteristics of distinct ash flows in a biomass thermal power plant with bubbling fluidised bed combustor. Energy 90, 387-402. https://doi.org/ 10.1016/j.energy.2015.07.036.

Tarelho, L.A.C., Teixeira, E.R., Silva, D.F.R., Modolo, R.C.E., Silva, J.J.F., 2012 Characteristics, management and applications of ashes from thermochemical conversion of biomass to energy, in: World Bioenergy 2012, Conference \& Exhibition on Biomass for Energy. Jonkopin, Sweden.

Teixeira, E.R., Camões, A., Branco, F.G. Tarelho, L.,2016a. Biomass and coal fly ash as cement replacement on mortar properties. In: ICCS16 - II International Conference on Concrete Sustainability, pp. 1-12.

Teixeira, E.R., Mateus, R., Camões, A., Branco, F.G., 2019. Quality and durability properties and life-cycle assessment of high volume biomass fly ash mortar. Constr. Build. Mater. 197, 195-207. https://doi.org/10.1016/J CONBUILDMAT.2018.11.173.

Teixeira, E.R., Mateus, R., Camões, A.F., Bragança, L., Branco, F.G., 2016b. Comparative environmental life-cycle analysis of concretes using biomass and coal fly ashes as partial cement replacement material. J. Clean. Prod. 112, 22212230. https://doi.org/10.1016/j.jclepro.2015.09.124.

Teixeira, E.R., Tarelho, L.A.C., Silva, T.C.S.R., Silva, D.F.R., Modolo, R.C.E., 2013 Physical-chemical characteristics of ash flows in a biomass thermal power plant. In: 21st European Biomass Conference and Exhibition. Copenhagen.

Tkaczewska, E., Małolepszy, J., 2009. Hydration of coal-biomass fly ash cement. Constr. Build. Mater. 23, 2694-2700. https://doi.org/10.1016/ j.conbuildmat.2008.12.018.

Tosti, L., van Zomeren, A., Pels, J.R., Comans, R.N.J., 2018. Technical and environmental performance of lower carbon footprint cement mortars containing biomass fly ash as a secondary cementitious material. Resour. Conserv. Recycl. 134, 25-33.

Van, V.-T.-A., Rößler, C., Bui, D.-D., Ludwig, H.-M., 2013. Mesoporous structure and pozzolanic reactivity of rice husk ash in cementitious system. Constr. Build. Mater. 43, 208-216. https://doi.org/10.1016/j.conbuildmat.2013.02.004.

Vassilev, S.V., Baxter, D., Andersen, L.K., Vassileva, C.G., 2013a. An overview of the composition and application of biomass ash. Fuel 105, 19-39. https://doi.org/ 10.1016/j.fuel.2012.10.001.

Vassilev, S.V., Baxter, D., Andersen, L.K., Vassileva, C.G., 2013b. An overview of the composition and application of biomass ash. Part 1. Phase-mineral and chemical composition and classification. Fuel 105, 40-76. https://doi.org/ 10.1016/j.fuel.2012.09.041.

Vassilev, S.V., Baxter, D., Andersen, L.K., Vassileva, C.G., 2010. An overview of the chemical composition of biomass. Fuel 89, 913-933. https://doi.org/10.1016/ j.fuel.2009.10.022.

Visser, J.H.M., 2014. Influence of the carbon dioxide concentration on the resistance to carbonation of concrete. Constr. Build. Mater. 67, 8-13. https://doi.org/ 10.1016/j.conbuildmat.2013.11.005.

Wang, S., Baxter, L., 2007. Comprehensive study of biomass fly ash in concrete: strength, microscopy, kinetics and durability. Fuel Process. Technol. 88, 11651170. https://doi.org/10.1016/j.fuproc.2007.06.016.

Wang, S., Llamazos, E., Baxter, L., Fonseca, F., 2008a. Durability of biomass fly ash concrete: freezing and thawing and rapid chloride permeability tests. Fuel 87 359-364. https://doi.org/10.1016/j.fuel.2007.05.027.

Wang, S., Miller, A., Llamazos, E., Fonseca, F., Baxter, L., 2008b. Biomass fly ash in concrete: mixture proportioning and mechanical properties. Fuel 87, 365-371. https://doi.org/10.1016/j.fuel.2007.05.026.

Zhang, Y.M., Sun, W., Yan, H.D., 2000. Hydration of high-volume fly ash cement pastes. Cem. Concr. Compos. 22, 445-452. https://doi.org/10.1016/S0958-9465 (00)00044-5.

Zomeren, A. Van, Comans, R.N.J., 2009. Carbon speciation in municipal solid waste incinerator (MSWI) bottom ash in relation to facilitated metal leaching. Waste Manag. 29, 2059-2064. https://doi.org/10.1016/j.wasman.2009.01.005. 